\title{
Antibacterial Activity of Medicinal Plants Used in the Management of HIV/AIDs Opportunistic Infections in Njeru Sub County, Buikwe District
}

\author{
Mustapha W. Shehu ${ }^{1 *}$, Nafi'u Abdulkadir ${ }^{2 * *}$, Idris Bello ${ }^{3}$, Abdulaziz Shehu$^{1}$, Sadiya A. Waziri ${ }^{4}$ \\ ${ }^{1}$ Department of Environmental Science, Faculty of Science, Islamic University in Uganda \\ ${ }^{2}$ Department of Microbiology, Faculty of Science, Sokoto State University, Sokoto Nigeria \\ ${ }^{3}$ Department of Pharmacology, School of Pharmaceutical Sciences, Universiti Sains Malaysia (USM), 11800, Pulau \\ Pinang, Malaysia. \\ ${ }^{4}$ Department of Chemistry, Faculty of Science, Usmanu Danfodiyo University, Sokoto Nigeria \\ *Email: shehumustapha3@gmail.com, \\ **Email: nafiuabdulkadir523@gmail.com
}

\begin{abstract}
Infectious diseases such as skin infection, chronic cough, stomach infection, tuberculosis, diarrhoea, warts, herpes zoster and others were claimed to be treated using medicinal plants. The study was aimed at determining the antibacterial activity and determination of bioactive compound of some medicinal plants used in management of HIV/AIDS opportunistic infections. A total of six plants were subjected to phytochemical and three out of six were tested against bacterial pathogens. The aqueous extracts of plants leaves of Pseudospondias microcarpa (PM), Callistemon citrinus (CC) and Spathodea campanulata (SC) were tested against two bacterial pathogens namely: Staphylococcus aureus and Pseudomonas aeruginosa. The result revealed the presence of Saponins, Tannins, Anthracenosides and Steroid glycosides. Alkaloids, flavonoids and reducing sugars had narrow distribution among the species. The highest clear zones were found in PM against Staphylococcus aureus $(21.18 \mathrm{~mm})$ followed by $20.07 \mathrm{~mm}$ for CC and $19.03 \mathrm{~mm}$ for PM against the same bacterium. For Pseudomonas aeruginosa $20.36 \mathrm{~mm}$, was recorded for PM, $21.3 \mathrm{~mm}$ for CC and $20.16 \mathrm{~mm}$ for Sc at different concentration. The antibiotic used as control revealed highest against all the tested bacteria. There was no significant difference between the bacterial activities of the extracts of the three plant species but it varied significantly across the different serial dilutions. Further studies should be conducted on phytochemical analysis to establish more active ingredients that may be used in the development of drugs by pharmaceutical companies.
\end{abstract}

Keywords: Antibacterial, bacterial pathogens, bioactive compounds, HIV/AIDS, medicinal plants

\section{Introduction}

Traditional medicine refers to any ancient, culturally based healthcare practice different from scientific medicine and it is commonly regarded as indigenous, unorthodox, alternative or folk and a largely orally transmitted practice used by communities with different cultures [1]. Such use and practice of medicinal plants for the management of infection are vital to human life. According to Yadava and Jithendra [2], plant medication is believed to be an important healthcare system, which mainly involves the use of locally available medicinal plants.

Medicinal plants produce a variety of compounds of known therapeutic properties with antimicrobial activity which has been revived as a current resistance profiles associated with appropriate use of antibiotics [3]. Medicinal plants still remain the main resource for management of the infections related to HIV/AIDS infected people living in the local communities. The wide use of traditional medicine among local communities could be attributed to cultural acceptability, economic affordability and efficacy against certain type of diseases as compared to modern medicines [2]. The therapeutic properties of various medicinal plants have been used to treat human diseases. It has been estimated that between $60-90 \%$ of the population of developing countries use traditional and botanical medicines [4].

Sayyed Mansour et al. [5] Results showed that the extract of C. citrinus showed a significant activity against the majority of bacteria which is comparable with standard antibiotics. An ethnobotanical 
survey conducted in Kadiogo Province of Burkina Faso, revealed that medicinal plants are used in the management of the oral health concerns: acute necrotizing gingivitis, loose teeth, dental abscesses, sores in the mouth, on the tongue and lips [6]. Traditional herbal use has been reported to be common among individuals with moderate and advanced HIV disease. In Africa, traditional medicinal plants are often used as primary management for HIV/AIDS opportunistic infections such as dermatological disease, pneumonia, depression, tuberculosis, insomnia, gastrointestinal and respiratory infections and weakness [7]. Plants remain the most common source of antimicrobial agents. Their usage as traditional health remedies is the most popular for $80 \%$ of world population [8-9]. However, the use of medicinal plant species in Uganda especially in Njeru sub-county persist, and is likely to increase substantially because of the increase in human population, ever increasing cases of infections with HIV and other diseases [10].

In Africa, traditional medicinal plants are often used as primary means for management of HIV/AIDS opportunistic infections such as dermatological disease, pneumonia, depression, tuberculosis, insomnia, gastrointestinal and respiratory infections and weakness [7]. Medicinal plants produce a variety of compounds of known therapeutic properties with antimicrobial activity which has been revived as a current resistance profiles associated with appropriate use of antibiotics [3]. It is expected that plant extracts showing target sites other than those used by antibiotics will be active against drug-resistant microbial pathogens. Plants use for managing HIV/AIDS opportunistic infections like Callistemon citrinus, Pseudospondias microcarpa, Spathodea campanulata and others species, have not been investigated very well in terms of antimicrobial activities. In Uganda, people use plants as medicines and nutritional supplements in the management of various infections associated with HIV/AIDS. Thus the study focused on testing antibacterial activity of medicinal plants used in management of HIV infections in Njeru sub county Uganda.

\section{Materials and Methods}

\subsection{Study Area}

Njeru sub-county is located within Buikwe District and it covers an area of $144 \mathrm{sq}$. km. It is 45 miles East of Kampla, the capital city of Uganda (Figure 2.1). It also lies North of the equator at latitude $0^{0} 28^{\prime} \mathrm{N}$ and longitude $32^{0} 12^{\prime} \mathrm{E}$ and altitude of $3845 \mathrm{ft}(1172 \mathrm{~m})$ above sea level. The climate is tropical with bimodal distribution of rainfall which peaks from March to May and reduces from August to November. Mean annual rainfall is $1295.6 \mathrm{~mm}$, while the minimum temperatures range from $15^{\circ} \mathrm{C}$ to $18.8^{0} \mathrm{C}$. Maximum temperatures range from $26.2^{0} \mathrm{C}$ to $30.2^{0} \mathrm{C}[11]$.

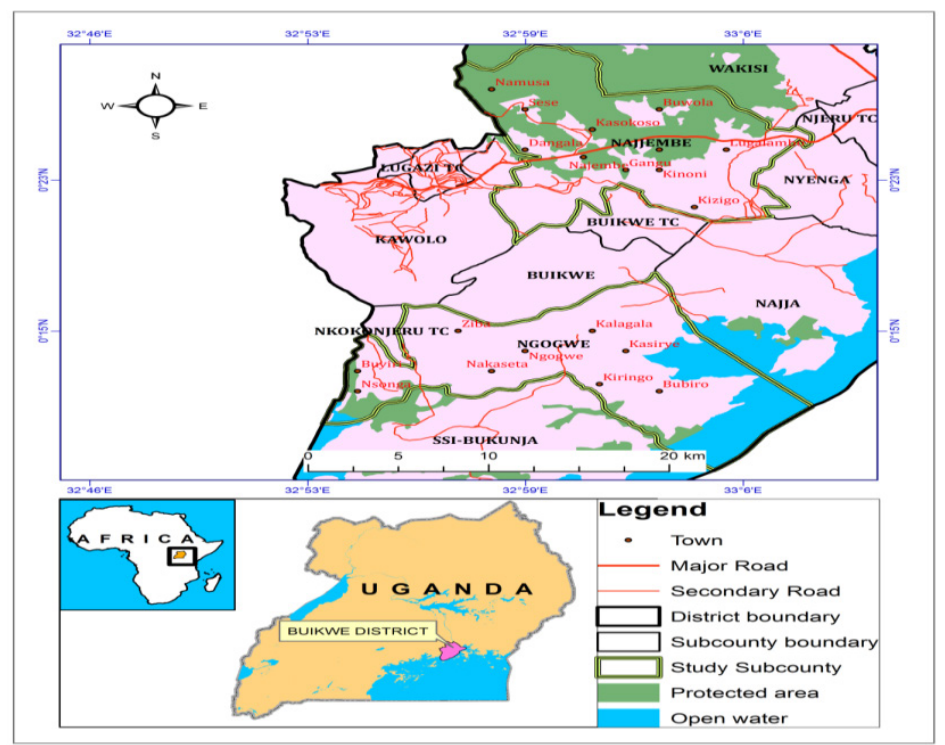

Figure 2.1: Map showing the location of the study area in Buikwe District 


\subsection{Sample Collection}

The plant materials were collected from the parishes of Njeru West (Namwezi village), Njeru East and Njeru South following the standard procedures described by [12]. Plant specimens were taken for identification at Makerere University Herbarium following the procedures described by [13]. The plant species were classified using Martin the Key database at www.theplantlist.org.

\subsubsection{Selection of Antibacterial Medicinal Plants for Bioassay and Phytochemical Screening}

A total of six (6) most frequently used medicinal plant species by TMPs (Traditional Medicinal Preactitioners) in study area were selected for phytochemical analysis and three out of six were selected for in vitro antibacterial activity. The plant species were; Pseudospondias microcarpa (A.Rich)Engl, Erythrina abyssinica D.C, Callistemon citrinus (Curtis) Skeels., Spathodea campanulata P. Beauv., Tetradenia riparia (Hochst) and Solenostemon latifolius (Hochst.ex Benth) J.K.Morton.

\subsubsection{Qualitative Chemical Analysis of Selected Medicinal Plants}

Different chemical tests were performed to establish the profile of aqueous extracts from the leaves of medicinal plant for their chemical composition. Chemical qualitative analysis for major active groups of compounds such as polyuronides, reducing sugars, saponins, tannins, alkaloids, anthraquinone, steroid gycoside, and flavonoids and anthocyanosides using standard qualitative methods of analysis as described by with modifications [14-15].

\subsubsection{Extraction of Plant Material and Preparation of Extract}

Sterile water was used as the extracting solvent for the plant materials. The collected fresh leaves of the 6 different plant species free from contamination were washed thoroughly 2-3 times with running tap water, leaf material were well air dried under shade, after complete shade drying the plant material grinded in mixer, the powder were kept in small plastic bags labeled with a paper. The grinded leaves material of $20 \mathrm{~g}$ of each plant were weighed using an electronic balance and crushed in $200 \mathrm{ml}$ of sterile water and filtered through a Whatman filter paper no 12 . The concentrated crude extracts were kept in separate containers and labeled appropriately.

\subsection{Preparation of Extract}

The method described by Ndip [16] was employed with some modifications for extract preparation. A set of six sterile test tubes were filled with sterile distilled water to capacity of $9 \mathrm{ml}$ using sterile micropipette. An amount of $3 \mathrm{ml}$ of the aqueous plant extract were pipetted and vortex thoroughly to dissolve and allowed to stand for 3 hours.

\subsection{Test Microorganism}

A stock culture of Staphylococcus aureous and pseudomonas aeruginosa were obtained from Department of Microbiology and Parasitology, College of Veterinary Medicine, Animal Resources and Biosecurity at Makerere University.

\subsection{Antibacterial Susceptibility Tests}

The Agar Well Diffusion Assay was done as described by Irshad et al. [17] with some modifications. The Agar well diffusion assay was used to test the activity of each aqueous extract on a culture of pathogenic bacteria. This was done by preparing Mueller-Hilton agar and nutrient agar on petri dishes and allowed them to solidify. A representative sample of the medium was incubated at 27 to $30^{\circ} \mathrm{C}$ for 24 hours and examined to verify its sterility. Four wells of approximately $10 \mathrm{~mm}$ diameter were dug into the petri dishes using a cork borer. The entire surface of the agar was inoculated with Staphylococcus aureus and pseudomonas aeruginosa respectively. An amount of $0.5 \mathrm{ml}$ of the aqueous plant extract were pipetted and separately introduced into the wells in the culture and incubated at $30^{\circ} \mathrm{C}$ for 24 hours to allow the inoculums establish fully. This was done in triplicates of plating. The diameters of the zones of inhibition around the wells were measured. Amphicilin was used as the positive control.

\subsection{Data Analysis}


The data generated during the course of study were analyzed using both Microsoft Excel and Statistical Package for Social Sciences (SPSS) version 20. ANOVA was used to test the significance difference in the effects of dilution of aqueous extracts from these three plants on the two bacterial pathogens (Staphylococcus aureus and Pseudomonas aeruginosa).

\section{Results and Discussion}

\subsection{Phytochemical Analysis of Some Selected Medicinal Plants}

The results from the qualitative screening of secondary metabolites in six selected medicinal plants used in the management of HIV/AIDS opportunistic infections showed that Saponins, tannins, anthracenosides and steroid glycosides were present in all species analyzed (Table 1). Alkaloids and reducing sugars were absent in Tetradenia riparia (Hochst) and Solenostemon latifolius (Hochst.ex Benth) J.K.Morton. Anthocyanosides were only present in Spathodea campanulata and Solenostemon latifolius. Flavonoides were in high quantity in all plants specie identified except in Erythrina abyssinica D.C. Spathodea campanulata contained all the secondary metabolites that were analyzed with their content within the range of low, moderate to high quantity.

Table 1: Phytochemical analysis result of some selected medicinal plants

\begin{tabular}{|c|c|c|c|c|c|c|}
\hline Secondary metabolites & $\mathrm{PM}$ & EA & $\mathrm{CC}$ & $\mathrm{SC}$ & TR & $\mathrm{SL}$ \\
\hline Polyuronides & - & + & - & +++ & + & ++ \\
\hline Reducing sugars & ++ & + & ++ & +++ & - & 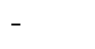 \\
\hline Saponins & +++ & ++ & + & ++ & +++ & +++ \\
\hline Tannins & +++ & + & +++ & +++ & ++ & +++ \\
\hline Alkaloides & ++ & +++ & + & + & - & - \\
\hline Anthracenosides & +++ & + & +++ & +++ & +++ & ++ \\
\hline Steriod glycosides & ++ & ++ & +++ & ++ & +++ & ++ \\
\hline Flavonoides & +++ & - & +++ & +++ & +++ & +++ \\
\hline Anthocyanosides & - & - & - & +++ & - & +++ \\
\hline
\end{tabular}

Key: PM, EA, CC, SC, TR and SL represent Pseudospondias microcarpa (A.Rich)Engl, Erythrina abyssinica D.C, Callistemon citrinus (Curtis) Skeels., Spathodea campanulata P. Beauv., Tetradenia riparia (Hochst) and Solenostemon latifolius (Hochst.ex Benth) J.K.Morton respectively while,,++++++ and - denotes, low quantity, moderate quantity, high quantity and absent, respectively.

The secondary metabolites detected known to have medicinal properties. For example, tannin played a role in inhibiting the growth of bacteria by reacting with protein on the cell wall. Dev [18] also reported that tannin rich medicinal plants are used as healing agents in a number of diseases and saponins were known to be immune booster [19]. Some phytochemical compounds already known to have antibacterial properties were present in some of the plants screened. Latte and Kolodziei [20] reported that tannins have been demonstrated to have a powerful antifungal and antibacterial action in clinical studies and also have wound healing and antiseptic effects therefore, the tannins present in all the plant species analyzed in this study could be responsible for their antibacterial activity and can justify the ethnobotanical uses of the plant species by the local people.

\subsection{Anti-bacterial Activity of Some Selected Medicinal Plants}

Three plants namely Pseudospondias microcarpa, Callistemon citrinus and Spathodea campanulata were selected for the anti-bacterial activity based on the presence of secondary metabolites identified in phytochemical analysis. The activities of three plant aqueous extracts were tested against two bacterial strains namely: Staphylococcus aureus and Pseudomonas aeruginosa. The aqueous extract's zone of inhibition diameter with Staphylococcus aureus was $17.70 \mathrm{~mm}, 21.18 \mathrm{~mm}$ and $12.75 \mathrm{~mm}$ for Pseudospondias microcarpa, Callistemon citrinus and Spathodea campanulata respectively. With 
Pseudomonas aeruginosa it was $21.30 \mathrm{~mm}, 20.36 \mathrm{~mm}$ and $20.16 \mathrm{~mm}$ for Pseudospondias microcarpa, Callistemon citrinus and Spathodea campanulata, respectively (Table 1).

Table 2: Zone of inhibitions for antibacterial activity of plant extracts against Staphylococcus aureous and Pseudomonas aeruginosa using serial dilutions

\begin{tabular}{|c|c|c|c|c|c|c|c|}
\hline \multirow[b]{2}{*}{ Test organisms } & \multirow{2}{*}{$\begin{array}{l}\text { Plants } \\
\text { extract }\end{array}$} & \multicolumn{6}{|c|}{$\begin{array}{l}\text { Zone of inhibition diameter }(\mathrm{mm}) \\
\text { At varying Concentrations }\end{array}$} \\
\hline & & $20 \mathrm{mg} / \mathrm{ml}$ & $30 \mathrm{mg} / \mathrm{ml}$ & $40 \mathrm{mg} / \mathrm{ml}$ & $50 \mathrm{mg} / \mathrm{ml}$ & $60 \mathrm{mg} / \mathrm{ml}$ & $90 \mathrm{mg} / \mathrm{ml}$ \\
\hline \multirow{4}{*}{$\begin{array}{l}\text { Staphylococcus } \\
\text { aureus }\end{array}$} & $\mathrm{CC}$ & 20.07 & 17.7 & 11 & 10 & 10 & 10 \\
\hline & $\mathrm{PM}$ & 21.18 & 19.03 & 13.68 & 10 & 10 & 10 \\
\hline & $\mathrm{SC}$ & 12.75 & 10.33 & 10 & 10 & 10 & 10 \\
\hline & Antibiotic & 30.60 & 30.37 & 30.90 & 30.03 & 30.27 & 30.61 \\
\hline \multirow{4}{*}{$\begin{array}{l}\text { Pseudomonas } \\
\text { aeruginosa }\end{array}$} & $\mathrm{CC}$ & 21.3 & 20.25 & 12.35 & 10.88 & 10 & 10 \\
\hline & $\mathrm{PM}$ & 20.36 & 18.81 & 15.53 & 11.05 & 10 & 10 \\
\hline & $\mathrm{SC}$ & 20.16 & 17.16 & 12.66 & 10 & 10 & 10 \\
\hline & Antibiotic & 33.34 & 32.37 & 32.78 & 32.82 & 32.11 & 31.81 \\
\hline
\end{tabular}

The above table illustrates that the plant extracts which were serially diluted at $20 \mathrm{mg} / \mathrm{ml}, 30 \mathrm{mg} / \mathrm{ml}$, $40 \mathrm{mg} / \mathrm{ml}, 50 \mathrm{mg} / \mathrm{ml}, 60 \mathrm{mg} / \mathrm{ml}$, and $70 \mathrm{mg} / \mathrm{ml}$ showed the zone of inhibition against Staphylococcus aureus and Pseudomonas aeruginosa. The first set of three dilutions were more active as indicated by greater zone of inhibition against bacterial pathogens than the last three set of dilutions which showed no inhibitions against Staphylococcus aureus and last two set of dilutions against Pseudomonas aeruginosa. The minimum zone of inhibition was observed at concentration of $50 \mathrm{mg} / \mathrm{ml}$ against Pseudomonas aeruginosa. The less effective activity of the last three set of dilutions was due to dilution effect.

To test the difference in the effects of aqueous extracts of leaves from three different plants against two pathogens (Staphylococcus aureus and Pseudomonas aeriginosa), a one-way ANOVA was conducted. There was no significant difference in the effects of aqueous extracts from Pseudospondias microcarpa, Callistemon citrinus and Spathodea campanulata on Staphylococcus aureus and Pseudomonas arginosa (ANOVA, $\mathrm{p}=0.284$ ). This implies that the three plants can effectively manage the diseases caused by Staphylococcus aureus and Pseudomonas arginosa, and probably with other bacterial species.

To test the difference in the effects of dilution of aqueous extracts from these three plants on the two pathogens (Staphylococcus aureus and Pseudomonas arginosa). The effect of the three plant species Pseudospondias microcarpa, Callistemon citrinus and Spathodea campanulata on Staphylococcus aureus and Pseudomonas arginosa varied significantly across the dilutions on (ANOVA, $<<0.001$ ), with higher antibacterial activity associated with low dilutions. This implies that for the extract to be effective, they have to be taken at higher concentrations. Therefore, the finding revealed that there was an activity of all the medicinal plants studied against Staphylococcus aureus and Pseudomonas aeruginosa. However, there was a significant difference on the dilutions of these aqueous extracts. Hence, the lower the concentration of these aqueous extract from the medicinal plants, the less the bacterial activities. By considering the zones of inhibition as a measure of plant extracts activity, a study from Kakudidi et al. [21] showed both the ether and ethanol extracts of $T$. riparia were more active against $C$. albicans whereas studies have mentioned $T$. riparia and some other plant species to be used in treating fungal, bacterial or viral infections and other diseases in different parts of Africa [22]. Another study from Godwin [23] on phytochemical and antibacterial activity of crude extracts of the pod of Aframomum angustifolium (Sonn.) K. Schum. Using methanol extract showed the strongest antibacterial activity against $S$. aureus of $18.5 \mathrm{~mm}$. The aqueous extracts of the selected plant species possess antibacterial activity, thus justifying the use of these plants for managing HIV opportunistic infections.

\section{Conclusion}

This antibacterial study of the plant extracts demonstrated the presence of all secondary metabolites which were found to be active ingredients to fight against the diseases agent. It also indicated the plants 
are effective against the tested bacterial pathogens which are frequently found to cause diseases. Three plants Pseudospondias microcarpa, Callistemon citrinus and Spathodea campanulata were selected for the anti-bacterial activity. The activities of three plant aqueous extracts tested against Staphylococcus aureus and Pseudomonas aeruginosa exhibited high inhibition diameter at varying concentration. Hence tested plant can serve as a good source of alternative for drug formulation. Further research is needed to investigate toxicity and side effects of the plants.

\section{References}

1. Lulukal Ermias, Ensermu Kelbess, Tamrat Bekele and Haile Yineger. 2008. An ethnobotanical study of medicinal plants in Mana Angetu District, Southeastern Ethiopia. Journal of Ethnobiolology and Ethnomedicine, 4(10): $1746-1752$.

2. Yadava Raj Nath, Jithendra Bhangale. 2008. New antibacterial triterpenoid saponin from Lactuca scariola. Fitotherapia, 79: 245-249.

3. Chattopadhyay Rabi Ranjan, Bhattacharyya Sabir Kumar, Medda Chiranjib, Chanda Sunanda, and Bag Anwesa. 2009. A comparative evaluation of antibacterial potential of some plants used in Indian traditional medicine for the treatment of microbial infections. Braz Arch Biol Technol, 52: 1123-1128.

4. World Health organization. 2002a. Traditional medicine strategy 2002-2005. WHO, Geneva.

5. Seyyed Mansour Seyydnejad, Masumeh Niknejad, Ismaieel Darabpoor and Hossein Motamedi. 2010. Antibacterial Activity of Hydroalcoholic Extract of Callistemon citrinus and Albizia lebbeck, American . of ApplScie. 7 (1): 1316 .

6. Tapsoba Hadissa and Deschamps Jean.-Pierre. 2006. Use of medicinal plants for the treatment of oral diseases in Burkina Faso. Journal of Ethnopharmacology, 104: 68-78.

7. Hodgson Tim, Rachanis Chris. 2002. Oral fungal and bacterial infections in HIV-infected individuals: an overview in Africa. Journal of Oral Diseases, 8: 80-87.

8. Bibitha B, Jisha V K, Salitha C V, Mohan S and Valsa A K 2002, "Antibacterial Activity of Different Plant Extracts, Short Communication", Indian J. Microbiol., Vol 42, pp. 361 - 363.

9. Maghrani M, Zeggwal N, Michel J and Eddouks M (2005), "Antihypertensive Effect of Lepidium sativum in Spontaneously Hypertensive Rats”, J. Ethnopharm., Vol. 102, Nos. (1-2), pp. 193-197.

10. Rukangira Ernest. 2001. Medicinal Plants and Traditional Medicine in Africa: Constraints and Challenges. Sustainable Development International, 179-180.

11. National Agricultural Organisation, Uganda. 2005. Report of farming systems and livelihoods in south western ecological zone of Uganda.

12. Hue Nguyen Van, Uchida Rampei, Ho M Cheiem. 2000. Sampling and analysis of soils and plant tissues how to take representative samples, how the samples are tested from. In: Silva JA,Uchida R, Ho MC, editors. Plant nutrient management in Hawaii's soils, approaches for tropical and subtropical agriculture. College of Tropical Agriculture and Human Resources, University of Manoa. PP 2-4.

13. Martin W Karen, and Ernst Edzard. 2004. Herbal medicines for fungal infections: a systematic review of a controlled clinical trial. Mycoses, 47:87-92.

14. Soforowa A 1993. Medicinal Plants and Traditional Medicine in Africa, John Wiley and Son Ltd., pp. 150-153.

15. Evans, W. C. Trease and Evans (1999).Pharmacognosy 14th Edition W. B. Saunders Company Limited, New York pp1-340.

16. Ndip, R.N., A.E. Malange, A.E. Tarkang, S.M. Mbullah, H.N. Luma, A. Malongue, L.M. Ndip, K. Nyongbela, C. Wirmum And S.M.Efange. 2007. In vitro anti-Helicobacter pylori activity of extracts of selected medicinal plants from North West Cameroon.Journal of Ethnopharmacology, vol. 114, pp. 452-457.

17. Irshad, S., M. Mahmood, and F. S. Perveen. (2012). In-Vitro anti-bacterial activities of three medicinal plants using agar well diffusion method. Research Journal of Biology, vol. 02, no. 01, pp. 1-8.

18. Dev Sukh. 2010. Impact of natural products in modern drug development: Review article. Indian Journal of Experimental Biology, 48:191-198.

19. Choi Ran Joo, Ngoc Tran Minh, Bae K., Cho H. J, Kim Dae-Duk, Chun, J S., and Kim Y S. 2013. Antiinflammatory properties of anthraquinones and their relationship with the regulation of P-glycoprotein function and expression. European Journal of Pharmaceutical Science, 48:272-281. 
20. Latte Klaus Peter, Kolodziei Herbert. 2000. Antifungal effects of hydrolysable tannins and related compounds on dermatophytes mould fungi and yeasts Zeitschrift Nature forschung, 55:467-472.

21. Kakudidi Esezah, Ayorekire Fredric, Okeng-Ogwa Jasper and Anywar Godwin. 2015. Phytochemical analysis and screening of Ugandan medicinal plants for antifungal activity against Candida albican, Intert'nal J. of trop. Diseas. \& health, $\mathbf{9}(\mathbf{1}): 1-8$.

22. Bunalema Lydia, Obakiron S, John Robert Stephen Tabuti, and Waako Paul. 2014 Knowledge on plants used traditionally in the treatment of tuberculosis in Uganda. Journal of Ethnopharmacol, 151:999-1004.

23. Godwin Upoki Anywar and Claude Kirimuhuzya. 2015. Phytochemical and antibacterial activity of crude extracts of the pod of Aframomum angustifolium (Sonn.) K. Schum: European Journal of biological research. $5(2): 1-6$. 